Jurnal Penelitian Pendidikan, Psikologi Dan Kesehatan (J-P3K) 2020, Vol. 1 (No. 3) : 232-242

\title{
Hubungan Sense of humor dengan Depresi pada Remaja Putri di Pondok Pesantren Hidayatullah
}

\section{The Correlation between Sense of humor and Depression to Young Women in Islamic Boarding Schools Hidayatullah}

\author{
Firmawati* \\ Sekolah Tinggi Ilmu Psikologi Harapan Bangsa, Indonesia \\ Disubmit: 14 Oktober 2020; Diproses: 14 Oktober 2020; Diaccept: 23 November 2020; Dipublish: 01 Desember 2020 \\ *Corresponding author: E-mail: psi.firma87@gmail.com
}

\begin{abstract}
Abstrak
Penelitian ini bertujuan untuk mengetahui hubungan depresi dengan sense of humor pada remaja putri di Pondok Pesantren Hidayatullah. Penelitian ini menggunakan pendekatan kuantitatif dengan metode korelasi, pengambilan sampel menggunakan study populasi. Populasi dalam penelitian ini berjumlah 40 santri putri di Pondok pesantren Hidayatullah. Instrumen yang digunakan adalah angket sense of humor menurut Eysenck (dalam Safarian dan Saputra, 2009) dengan angket depresi berdasarkan teori Beck (dalam Lubis 2009). Penelitian dianalisis dengan menggunakan teknik korelasi product moment dan bantuan program SPSS 24.0 for Windows. Hasil penelitian menunjukkan bahwa ada hubungan antara sense of humor dengan depresi pada remaja putri di pondok pesantren Hidayatullah sebesar 35.6\%. Kondisi tersebut menjelaskan bahwa para santri di pondok pesantren Hidayatullah merasa nyaman dan lebih mudah menggunakan sense of humor sebagai media untuk mengatasi depresi yang mereka hadapi.
\end{abstract}

Kata Kunci: Depresi; Sense of Humor; Remaja

\begin{abstract}
This study aims to determine the correlation between depression and a sense of humor in adolescent girls at Hidayatullah Islamic Boarding School. This study uses a quantitative approach with a correlation method, the sampling uses a population study. The population in this study amounted to 40 female students at the Hidayatullah Islamic Boarding School. The instrument used was a sense of humor questionnaire according to Eysenck (in Safarian and Saputra, 2009) with a depression questionnaire based on Beck's theory (in Lubis 2009). The research was analyzed using the product moment correlation technique and the help of the SPSS 24.0 for Windows program. The results showed that there was a relationship between a sense of humor and depression in young women at the Hidayatullah Islamic boarding school at 35.6\%. This condition explains that the students at the Hidayatullah Islamic boarding school feel comfortable and find it easier to use a sense of humor as a medium to overcome the depression they face.
\end{abstract}

Keywords: Depression; Sense of Humor; Teen

Rekomendasi mensitasi :

Firmawati. 2020, Hubungan Sense of humor dengan Depresi pada Remaja Putri di Pondok Pesantren Hidayatullah. Jurnal Penelitian Pendidikan, Psikologi dan Kesehatan (J-P3K),1 (3): 232-242. 


\section{PENDAHULUAN}

\section{Remaja}

merupakan

masa

perubahan dari anak-anak menuju ke arah kedewasaan, dimana terjadi peralihan dari masa kanak-kanak menuju masa dewasa dengan rentan usia 11-20 tahun (Hurlock, 2011).

Pada masa peralihan tersebut, sebagian besar remaja lebih banyak menghabiskan waktu untuk berkumpul bersama teman-teman, namun demikian kontrol dari orang tua sangat diperlukan untuk mendampingi proses kedewasaannya. Sebagian remaja sudah tinggal terpisah dari orang tua karena mengenyam pendidikan di pondok pesantren atau lembaga pendidikan islam.

Pada dasarnya pesantren bersifat mandiri, tidak tergantung kepada Pemerintah atau kekuasaan lainnya. Pesantren di Indonesia bisa memegang teguh kemurniannya sebagai lembaga pendidikan Islam sehingga tidak mudah di susupi ajaran-ajaran yang tidak sesuai dengan ajaran islam, sehingga tidak semua individu mampu mendirikan pondok pesantren sebagai lembaga pendidikan islam.

Sebagian besar pondok pesantren di Indonesia tidak membebankan biaya yang tinggi kepada para santri, namun demikian tidak dipungkiri terdapat pondok pesantren modern yang membebankan biaya yang tinggi kepada santri, akan tetapi biaya yang tinggi tersebut tidak melebihi biaya di institusi pendidikan lainnya. Santri yang berada di sebuah pondok pesantren datang dari berbagai latar belakang yang berbedabeda dengan membawa persoalan masingmasing.
Oleh karena itu dunia asrama merupakan dunia yang rentan terjadinya gangguan emosi. Tuntutan-tuntutan yang ada di sekolah dan asrama seperti sistem kedisplinan waktu, berbagai persoalan dengan teman dan guru, jadwal pelajaran yang banyak dan padat dapat menjadi faktor penyebab stres tersebut., menghadapi tuntutan-tuntutan di sekolah berasrama. Menurut Ardjanam (2007) yang menjelaskan bahwa "remaja yang berada di Pesantren memiliki permasalahan yang berbeda dari setiap remaja umumnya".

Ketidakmampuan melakukan adaptasi dengan lingkungan asrama menimbulkan kekacauan dalam jiwa remaja yang menyebabkan munculnya depresi tingkat ringan maupun berat. Peningkatan tingkat depresi seirng pertambahan usia, setelah mengalami masa pubertas. Kemudian sistem kelola asrama yang sering kali kurang memperhatikan aspek-aspek kejiwaan remaja, serta suasana yang kurang menyenangkan dapat menimbulkan tekanan seperti stress dan depresi.

Menurut Beck (Lubis, 2009) depresi adalah "suatu keadaan dimana individu merasa tertekan karena merasa hidup tidak bermakna dan kehilangan harapan hidup". Kecenderungan depresi merupakan gangguan dengan suasana perasaan yang sedih, murung, pemikiran bahwa dirinya tidak berharga, bersalah, hingga ciri somatik seperti kelelahan, gangguan pola makan dan tidur. Selanjutnya Beck menjelaskan beberapa gejala emosi terdiri dari 4 yaitu : emosi, motivasi, kognisi, fisik dan vegetatif. 
Masa ini juga sering disebut peralihan antara masa kanak-kanak dan masa dewasa, yang dimulai pada saat terjadinya kematangan seksual yaitu antara usia 11 sampai 20 tahun, termasuk siswa-siswi sekolah menengah ke atas.

Pada masa peralihan ini, remaja lebih tertarik menghabiskan waktunya dengan teman sebaya namun peranan orang tua tetap dibutuhkan dalam mengantarkan putra-putrinya menuju kedewasaan. Tetapi ada sebagian remaja yang tinggal terpisah dari orang tuanya sejak memasuki awal remaja sudah tinggal di pesantren.

Pondok Pesantren yang dimaksud adalah lembaga pendidikan Islam yang merupakan produk budaya Indonesia. Keberadaan Pesantren di Indonesia dimulai sejak Islam masuk negeri ini dengan mengadopsi sistem pendidikan keagamaan yang sebenarnya telah lama berkembang sebelum kedatangan Islam. Sebagai lembaga pendidikan yang telah lama berurat akar di negeri ini.

Pondok pesantren diakui memiliki andil yang besar terhadap perjalanan sejarah bangsa. Banyak pesantren di Indonesia hanya membebankan para santrinya dengan biaya yang rendah, meskipun beberapa pesantren modern membebani dengan biaya yang lebih tinggi jika dibandingkan dengan beberapa institusi pendidikan lainnya yang sejenis, pesantren modern jauh lebih murah.

Santri yang tinggal di asrama sebuah pondok pesantren datang dari berbagai latar belakang yang berbedabeda dengan membawa persoalan masingmasing. Oleh karena itulah dunia asrama merupakan dunia yang rentan terjadinya gangguan emosi.
Tuntutan-tuntutan yang ada di sekolah dan asrama seperti sistem kedisplinan waktu, berbagai persoalan dengan teman dan guru, jadwal pelajaran yang banyak dan padat dapat menjadi pemicu timbulnya stres karena ketidakmampuan menghadapi tuntutantuntutan di sekolah berasrama.

Menurut Ardjanam (2007) yang menjelaskan bahwa "remaja yang tinggal di pesantren memiliki dilematika permasalahan remaja yang relatif berbeda dengan para remaja pada umumnya". Ketidakmampuan menyesuaikan diri dengan lingkungan dapat menyebabkan kekacauan dalam kejiwaan remaja, antara lain berupa depresi, ringan, sedang, maupun berat.

Sistem kelola asrama yang kurang memperhatikan aspek-aspek kejiwaan remaja, sarana dan prasarana yang kurang memadai, serta suasana yang kurang menyenangkan sering kali dapat menimbulkan gangguan emosi seperti stress dan depresi. Menurut Beck (Lubis, 2009) depresi adalah "suatu kondisi individu yang merasa begitu tertekan, hidup tak berarti dan tak mempunyai harapan".

Depresi meningkat seiring pertambahan usia, terutama setelah melalui masa pubertas. Kecendrungan depresi merupakan gangguan perasaan yang merasa begitu tertekan, hidup tak berarti dan tak mempunyai harapan. motivasi, kognisi, fisik dan vegetatif.

Remaja dalam kategori sedang mengalami depresi akan menunjukkan rasa sedih atau gelisah yang berkelanjutan, waktu tidur yang terlalu sedikit, disertai dengan bangun tiba-tiba pada tengah malam atau pagi hari, 
kurangnya minat pada aktivitas yang pernah dinikmati, kesulitan untuk konsentrasi, mengingat hal, dan membuat keputusan dan adanya bersalah, tidak berguna, atau putus asa.

Menurut Hawari (Looker \& Gregson, 2005) mendefenisikan depresi adalah "suatu bentuk perasaan yang ditandai dengan kurangnya semangat hidup, tidak ada gairah hidup, mudah putus asa dan merasa diri tidak berguna untuk orang lain". Remaja dalam proses perkembangan memiliki kecendrungan untuk mengalami depresi, hal tersebut karena remaja sedang mengalami masa peralihan, sehingga sangat diharapkan adanya bimibingan dan dukungan psikologi dari keluarga terdekat. Remaja juga belum mampu membedakan antara depresi yang disebabkan mood yang normal pada remaja dengan depresi yang patologis.

Sulitnya remaja membedakan antara depresi yang disebabkan mood yang normal pada remaja dengan depresi yang patologis mengakibatkan depresi yang muncul tidak terdiagnogsis. Sehingga perlu adanya pemulihan yang berkesinambungan agar tidak berlanjut sampai dewasa.

Begitupun dalam menetapkan depresi yang terjadi pada remaja berasrama. Pondok pesantren rata-rata memiliki peraturan khusus dalam mengelola asramanya maupun pendidikan didalamnya. Dan beberapa pondok pesantren masih menggunakan peraruran-peraturan baku. Walaupun sudah banyak pesantren modern.

Salah satu yang terkadang membuat para santri didalamnya serba salah berkaitan dengan humor. Hal ini disebabkan humor identik dengan tertawa (mengeluarkan suara), melucu (membuat teman-temannya tertawa), bahkan ada yang tertawa terbahak-bahak. Sedangkan di dunia Pondok Pesantren hal seperti ini masih dianggap sebuah hal yang tabu. Dikarenakan santri mendapatkan kesan negatif dan dianggap tidak serius dalam menuntun ilmu. Padahal seperti yang diketahui bahwasannya salah satu cara mengatasi depresi yang dimiliki santri adalah dengan sense of humor yang mereka miliki. Remaja yang berada di asrama sebagian memiliki sense of humor .

Dimana mereka yang memiliki sense of humor ini sering menjadi objek teman-temannya untuk menghibur. Sehingga remaja yang memiliki sense of humor yang baik di asrama sering terlihat dikelilingi teman-temannya yang merasa terhibur dengan segala tingkah lakunya. Menurut Tjandra (Ripa, 2010) menjelaskan bahwa "Humor memiliki peranan tersendiri dalam membantu seseorang melalui kehidupan yang penuh dengan tantangan dan gejolak".

Humor yang dimiliki akan membantu individu menghadapi perubahan aspek kehidupan, memberikan ketenangan dan kenyamanan, dan mampu menghadapi setiap permasalahan yang terjadi, mampu berhadapan dengan situasi-situasi yang sangat sulit.

Seorang yang mampu menanggapi atau memahami humor yang disampaikan oleh orang lain adalah orang yang memiliki kepekaan terhadap humor tersebut. Seperti yang dijelaskan Sarlito (Safaria \& Saputra, 2009) yang menjelaskan bahwa "untuk dapat mengamati, merasakan atau mengungkapkan humor, individu dituntut 
untuk memiliki sense atau kepekaan". Individu memiliki tingkat humor yang tinggi dapat mengintropeksi setiap tindakan yang akan dilakukannya, memiliki cara pandang yang berbeda, memiliki alternatif dalam penyelesaian masalah karena dapat berfikir lebih fleksibel.

Sense of humor yang dimiliki oleh remaja berasrama dimanfaatkan oleh mereka untuk mengatasi segala macam persoalan dan dilema yang dihadapi mereka selama berada di asrama. Menurut Eysenck (Safaria \& Saputra, 2009) sense of humor adalah "kecendrungan individu untuk dapat mengatasi rasa sakit, marah, dan depresi". dan memiliki tiga aspek yaitu, Conformist Sense, Quantitative Sense, Productive Sense.

Sehingga sense of humor yang mereka miliki inilah yang membuat para remaja ini lebih bisa bertahan dan tidak terlalu tenggelam dalam situasi-situasi yang tidak menyenangkan. Remaja di dunia asrama menngunakan sense of humor yang mereka miliki dalam segala suasana. Sehingga mereka lebih nyaman dalam mengikuti segala kegiatan diasrama.

$$
\text { Menurut Hartanti }
$$

menjelaskan bahwa "dalam sebuah penelitian menunjukkan bahwa menggunakan humor juga dapat menciptakan suasana yang lebih rileks, serta membantu mengatasi pola sosial yang kaku dan formal sehingga dapat menghindari ketegangan". Hal ini dikarenakan humor mampu mengambangkan suasana hati yang positif (positif mood), seperti perasaan senang, gembira, bersuka ria, dan penuh harapan.
Berkumpulnya bermacam-macam bentuk karakter serta persoalanpersoalan yang dihadapi oleh santri seperti perceraian, ditinggalkan ayahnya, dibuang keluarganya, mempunyai ibu tiri yang tidak baik dll. Hal ini terkadang membuat mereka malas mengikuti pelajaran ataupun kegiatan sekolah dan pesantren, karena mereka merasa tidak mampu, sulit berkonsentrasi.

Bahkan ada beberapa santri yang suka menyendiri, tidak bersemangat bahkan ada yang merasa hidupnya sudah tidak berarti lagi. Dengan latar belakang seperti ini kemudian ditambah dengan berbagai macam persoalan di pesantren maka bisa timbul depresi. Apalagi menurut Brizendine (2005) "wanita lebih rentan akan depresi".

Mengatasi masalah yang dihadapi para santri mereka mempunyai strategi sendiri salah satunya yaitu sense of humor. Santri mengatasi segala persoalan yang mereka hadapi dengan humor disaat mereka bermain, belajar bersama bahkan sebelum tidur. Inilah yang membuat mereka sejenak melupakan segala persoalannya sehingga membuatnya lebih rileks.

Hal ini sesuai dengan Filipowicz (Safaria \& Saputra, 2009) yang menyatakan bahwa berbagai penelitian menunjukkan bahwa "humor dapat digunakan untuk memfasilitasi komunikasi dalam situasi sulit atau tegang". Sehingga mampu mengontrol terjadinya konflik interpersonal. Dengan menemukan humor dalam berbagai situasi dan tertawa lepas dengan lingkungan sekitar dapat dijadikan sebagai salah satu pemecahan terjadinya konflik interpersonal dan mampu 
menjadikan komunikasi yang lebih baik dan terbuka sehingga gangguan stress dan depresipun dapat diatasi.

Oleh karena itu santri bisa membuat kehidupanya menjadi lebih menyenangkan, dimana mereka terlihat senang mengikuti kegiatan-kegiatan yang positif, suka tertawa, dan bercanda bersama. Sense of humor dibuat berdasarkan aspek-aspek sense of humor yang dikemukakan oleh Eysenck (Safaria \& Saputra, 2009), yaitu : 1. Conformist sense, yaitu kesamaan apresiasi berupa pemahaman dan penghargaan individu tentang materi-materi kelucuan. 2. Quantitative sense, yaitu kuantitas atau seringnya individu tertawa, tersenyum, serta mudahnya individu merasa gembira.

3. Productive sense, yaitu kuantitas atau banyaknya individu menceritakan ceritacerita lucu dan mampu membuat individu lain bergembira. Depresi pada remaja jika berkepanjangan dapat mengakibatkan remaja tersebut bunuh diri yang berujung pada kematian.

Semakin lama individu mengalami depresi, maka akan semakin melemah daya tahan mentalnya, semakin terdistorsi pola pikir yang menyebabkan individu berpikir negatif sehingga tidak bisa melihat alternatif solusi, kondisi tersebut dapat menyebabkan remaja melakukan sesuatu hal yang tidak diharapkan oleh orang lain.

Adapun gejala-gejala yang dikemukakan oleh Beck (Lubis, 2009) yaitu: emosi sedih, menilai negatif diri sendiri, kurang senang pada diri sendiri, hilangnya rasa kasih sayang, menangis, hilangnya rasa bahagia, motivasi malas untuk melakukan sesuatu, menghindari, dan menarik diri, keinginan untuk bunuh diri, ketergantungan.

Kognisi rendahnya penilaian terhadap diri sendiri, tidak mempunyai harapan, menyalahkan diri sendiri, raguragu, penyimpangan terhadap dirinya sendiri. Fisik dan vegetatif tidak ada nafsu makan, kesulitan tidur, kelelahan. Remaja yang memiliki sense of humor yang tinggi dapat menangani masalah-masalah yang mengganggu kesehatan mental mereka karena humor dan kesehatan mental sangat erat kaitannya.

Menurut Allport (Bastaman, 2007) seorang ahli psikologi kepribadian setengah abad yang lalu telah menyatakan bahwa "eratnya kaitan antara rasa humor dengan kedewasaan pribadi dan kesehatan mental". Kepribadian yang baik menurut beliau ditandai dengan adanya kemampuan untuk mengenali diri meliputi kekuatan dan kelemahan dirinya, tidak mudah terbawa emosi, serta mampu melihat segi-segi humoritas berdasarkan pengalamannya. Hal ini berlaku bagi mereka yang masih memiliki rasa humor ataupun sense of humor.

Remaja yang memiliki sense of humor dapat membuat kepribadian mereka lebih sehat dan mampu menghadapi segala macam persoalan yang mengguncang mental mereka. Seseorang yang memiliki sense of humor yang tinggi lebih mampu dan lebih cepat menangkap humor, bahkan remaja yang memiliki sense of humor yang baik mampu memandang kehidupannya secara lebih luas dan lebih santai.

Cara pandang yang lebih luas dan santai terhadap kehidupannya dapat membuat mereka memberikan evaluasi yang lebih positif terhadap kehidupannya. 
Menurut Marten (Jones, 2010) mengungkapkan "humor dapat digunakan sebagai ungkapan perasaan ketika mengalami sesuatu yang tidak sesuai dengan yang diharapkan dan reaksi dari perasaan tersebut membawa kesenangan atau kebahagiaan".

Depresi diibaratkan seperti penyakit flu, sebab depresi dapat terjadi di semua kalangan, tidak terkecuali remaja. Menurut beberapa penelitian Fritz (Lubis, 2009) "sekitar 5\% dari remaja menderita simpton depresi, misalnya kesedihan yang menetap, prestasi yang menurun dan kurangya ketertarikan pada tugas yang dahulu disukai".

Remaja yang mengalami gangguan depresi akan menunjukkan gejala-gejala perasaan sedih yang berkepanjangan, suka menyendiri, sering melamun di dalam kelas/di rumah, kurang nafsu makan atau makan berlebihan, sulit tidur atau tidur berlebihan, merasa lelah, lesu kurang bertenaga, serasa rendah diri, sulit berkonsentrasi serta sulit mengambil keputusan.

Sense of humor yang dimiliki oleh remaja berasrama dimanfaatkan oleh mereka untuk mengatasi segala macam persoalan dan dilema yang dihadapi mereka selama berada di asrama. Menurut Eysenck (Safaria \& Saputra, 2009) sense of humor adalah "kecendrungan individu untuk dapat mengatasi rasa sakit, marah, dan depresi". dan memiliki tiga aspek yaitu, Conformist Sense, Quantitative Sense, Productive Sense. Sehingga sense of humor yang mereka miliki inilah yang membuat para remaja ini lebih bisa bertahan dan tidak terlalu tenggelam dalam situasisituasi yang tidak menyenangkan.
Remaja di dunia asrama menggunakan sense of humor yang mereka miliki dalam segala suasana. Sehingga mereka lebih rileks dalam beraktifitas mengikuti segala kegiatan di asrama. Menurut Hartanti (2008) menjelaskan bahwa "dalam sebuah penelitian menunjukkan bahwa menggunakan humor juga dapat menciptakan suasana yang lebih rilexs, serta membantu mengatasi pola sosial yang kaku dan formal sehingga dapat menghindari ketegangan".

Kondisi tersebut dikarenakan humor mampu mengambangkan suasana hati yang positif (positif mood), seperti perasaan senang, gembira, bersuka ria, dan penuh harapan. Berkumpulnya bermacammacam bentuk karakter serta persoalanpersoalan yang dihadapi oleh santri seperti perceraian, ditinggalkan ayahnya, dibuang keluarganya, mempunyai ibu tiri yang tidak baik dll. Hal ini terkadang membuat mereka malas mengikuti pelajaran ataupun kegiatan sekolah dan pesantren, karena mereka merasa tidak mampu, sulit berkonsentrasi.

Beberapa santri ditemukan ada yang suka menyendiri, tidak bersemangat bahkan ada yang merasa hidupnya sudah tidak berarti lagi. Dengan latar belakang seperti ini kemudian ditambah dengan berbagai macam persoalan di pesantren maka bisa timbul depresi. Apalagi menurut Brizendine (2005) "wanita lebih rentan akan depresi".

Strategi para santri mengatasi masalah yang dihadapi salah satunya yaitu sense of humor. Santri mengatasi segala persoalan yang mereka hadapi dengan humor disaat mereka bermain, belajar bersama bahkan sebelum tidur. Kondisi tersebut yang membuat mereka sejenak 
melupakan segala persoalannya sehingga membuatnya lebih rileks.

Hal tersebut sesuai dengan Filipowicz (Safaria \& Saputra, 2009) yang menyatakan bahwa berbagai penelitian menunjukkan bahwa "humor dapat digunakan untuk memfasilitasi komunikasi dalam situasi sulit atau tegang", sehingga mampu mengontrol terjadinya konflik interpersonal.

Dengan menemukan humor dalam berbagai situasi dan tertawa lepas dengan lingkungan sekitar dapat dijadikan sebagai salah satu pemecahan terjadinya konflik interpersonal dan mampu menjadikan komunikasi yang lebih baik dan terbuka sehingga gangguan stress dan depresi dapat diatasi.

Santri bisa membuat kehidupanya menjadi lebih menyenangkan, dimana mereka terlihat senang mengikuti kegiatan-kegiatan yang positif, suka tertawa, dan bercanda bersama.

Sense of humor dibuat berdasarkan aspek-aspek sense of humor yang dikemukakan oleh Eysenck (Safaria \& Saputra, 2009), yaitu:

1. Conformist Sense, yaitu kesamaan apresiasi berupa pemahaman dan penghargaan individu tentang materi-materi kelucuan.

2. Quantitative sense, yaitu kuantitas atau seringnya individu tertawa, tersenyum, serta mudahnya individu merasa gembira.

3. Productive sense, yaitu kuantitas atau banyaknya individu menceritakan cerita-cerita lucu dan mampu membuat individu lain bergembira.

Depresi pada remaja jika berkepanjangan dapat mengakibatkan remaja tersebut bunuh diri yang berujung pada kematian. Semakin lama seseorang mengalami depresi, semakin lemah daya tahan mental, habis energi dan semangatnya, terdistorsi pola pikirnya sehingga tidak bisa melihat alternatif solusi, tidak bisa melihat ke depan, tidak menemukan harapan dan tidak bisa berpikir positif.

Kondisi tersebut menyebabkan remaja melihat bahwa bunuh diri menjadi solusi satu-satunya. Adapun gejala-gejala yang dikemukakan oleh Beck (Lubis, 2009) yaitu:

1. Emosi

Sedih, Perasaan negatif terhadap diri sendiri, kurang senang terhadap diri sendiri, hilangnya rasa kasih sayang, menangis, hilangnya rasa bahagia,

2. Motivasi

Malas untuk melakukan sesuatu, menghindar, melarikan diri dan menarik diri, keinginan untuk bunuh diri, ketergantungan.

3. Kognisi

Rendahnya penilian terhadap diri sendiri, tidak mempunyai harapan, mencela dan mengalahkan diri sendiri, ragu-ragu, penyimpangan terhadap dirinya sendiri.

4. Fisik dan vegetatif

Tidak ada nafsu makan, kesulitan tidur, kelelahan.

Remaja yang memiliki sense of humor yang tinggi dapat menangani masalah-masalah yang mengganggu kesehatan mental mereka karena humor dan kesehatan mental sangat erat kaitannya. Menurut Allport (Bastaman, 2007) seorang ahli psikologi kepribadian setengah abad yang lalu telah menyatakan 
bahwa "eratnya kaitan antara rasa humor dengan kedewasaan pribadi dan kesehatan mental".

Kepribadian yang matang dan sehat menurut beliau ditandai antara lain oleh kemampuan memahami kekuatan dan kelemahan dirinya, tidak mudah terbawa emosi, serta mampu melihat segi-segi humoritas atas pengalaman dan keadaan dirinya. Hal ini berlaku bagi mereka yang masih memiliki rasa humor ataupun sense of humor. Remaja yang memiliki sense of humor dapat membuat kepribadian mereka lebih sehat dan mampu menghadapi segala macam persoalan yang mengguncang mental mereka.

Seseorang yang memiliki sense of humor yang tinggi lebih mampu dan lebih cepat menangkap humor, bahkan remaja yang memiliki sense of humor yang tinggi mampu memandang kehidupannya secara lebih luas dan lebih santai. Cara pandang yang lebih luas dan santai terhadap kehidupannya dapat membuat mereka memberikan evaluasi yang lebih positif terhadap kehidupannya.

Menurut Marten (Jones, 2010) menjelaskan "humor dapat digunakan sebagai reaksi emosi ketika sesuatu terjadi tidak sesuai dengan yang diharapkan dan reaksi emosi itu membawa kesenangan atau kebahagiaan". Sehingga sense of humor ini bisa digunakan untuk melupakan sejenak permasalahan yang ada.

\section{METODE PENELITIAN}

Penelitian ini menggunakan pendekatan kuantitatif dengan jenis penelitian yaitu korelasional. Menurut Hasan (2012) penelitian korelasional adalah mencari hubungan antara dua variabel atau lebih dengan tidak memberikan perlakuan pada subjek yang akan diteliti. Penelitian ini mencari besarnya nilai korelasi Sense of humor dengan Depresi.

Penelitian korelasi atau korelasional adalah suatu penelitian untuk mengetahui hubungan dan tingkat hubungan antara dua variabel atau lebih tanpa ada upaya untuk mempengaruhi variabel tersebut sehingga tidak terdapat manipulasi variabel (Frankel \& Wallen, 2008).

Penelitian korelasional menggunakan instrumen untuk menentukan apakah terdapat hubungan antara dua variabel atau lebih yang dapat dikuantitatifkan. Instrumen yang digunakan adalah angket sense of humor dengan depresi. Penelitian dianalisis dengan menggunakan rumus korelasi product moment dan bantuan SPSS Versi 24.0 for windows.

\section{HASIL DAN PEMBAHASAN}

Berdasarkan hasil penelitian dan analisis data yang pertama dapat diketahui bahwa 28 santri mengalami depresi sedang, 6 orang dalam kategori rendah dan 6 orang dalam kategori tinggi. Sehingga dapat dinyatakan bahwa depresi pada remaja putri di Pondok Pesantren Hidayatullah rata-rata masuk dalam kategori sedang.

Hal ini disebabkan berkumpulnya bermacam-macam bentuk karakter serta persoalan-persoalan yang dihadapi oleh santri maupun siswa seperti percerain, ditinggalkan ayahnya, keluarga yang tidak peduli, mempunyai ibu tiri yang tidak baik dan lainnya, belum lagi persoalanpersoalan diasrama terhadap sistem asrama itu sendiri, guru maupun teman.

Hasil analisis data penelitian yang kedua diketahui kategorisasi pada sense of 
humor sebanyak 25 santri masuk dalam kategori sedang, 6 orang dalam kategori rendah dan 9 orang dalam kategori tinggi.

Santri yang mempunyai sense of humor yang tinggi diharapkan mampu membantu teman-teman yang lainnya agar mampu meningkatkan sense of humor nya. Sehingga sense of humor ini bisa menjadi sebagai penghibur bahkan obat untuk mengatasi segala kejenuhan rutinitas yang mereka jalankan di pondok pesantren Hidayatullah.

Hasil penelitian yang ketiga dengan menggunakan Korelasi Regresi Linier, maka dapat di peroleh hasil sebagai berikut: koefisiennya sebesar $\mathrm{R}=0.597$, koefisien determinasi sebesar R2 $=0.356$. dengan tingkat siginifikan $=0.000$ yakini $\mathrm{P}$ $<0,05$ yang artinya siginifikannya masuk dalam kategori lemah hal ini menunjukkan bahwa sense of humor mempunyai hubungan yang positif sebesar 35.6\% dengan depresi namun pengaruh hubungan tersebut lemah.

Dengan adanya hubungan ini yang membuat para santri di pondok pesantren Hidayatullah terlihat ceria dan penuh tawa walaupun banyak beban hidup yang harus ditanggungnya. Karena ketika depresi menyerang mereka langsung mengatasinya dengan sense of humor, namun sense of humor tersebut tidak bisa benar-benar mengatasi depresi yang dihadapi para santri karena hubungan kedua variabel tersebut berada pada kategori lemah.

Para santri mengatasi masalahmasalah tersebut salah satunya yaitu sense of humor, dimana para santri mengatasi segala persoalan yang mereka hadapi dengan humor disaat mereka bermain bahkan belajar bersama bahkan sebelum tidur.

Kondisi tersebut membuat mereka sejenak melupakan segala persoalannya atau bahkan membuatnya lebih rileks. Hal ini sesuai dengan Filipowicz (Safaria \& Saputra, 2009) yang menyatakan bahwa berbagai penelitian menunjukkan bahwa "humor dapat digunakan untuk memfasilitasi komunikasi dalam situasi sulit atau tegang".

Dengan menemukan humor dalam berbagai situasi dan tertawa lepas dengan lingkungan sekitar dapat dijadikan sebagai salah satu pemecahan terjadinya konflik interpersonal dan mampu menjadikan komunikasi yang lebih baik dan terbuka sehingga gangguan stres dan depresi pun dapat diatasi.

\section{SIMPULAN}

Berdasarkan hasil penelitian diatas dapat disimpulkan bahwa ada hubungan antara sense of humor dengan depresi pada remaja putri di pondok pesantren Hidayatullah sebesar 35.6\%. Kondisi tersebut menjelaskan bahwa para santri di pondok pesantren Hidayatullah merasa nyaman dan lebih mudah menggunakan sense of humor sebagai media untuk mengatasi depresi yang mereka hadapi.

Para santri atau siswa menggunakan sense of humor disaat mereka mulai jenuh dan mengalami depresi. biasanya dilakukan di sela-sela kegiatan asrama, waktu santai bahkan saat akan tidur. Sehingga hubungan ini membuat para santri di pondok pesantren Hidayatullah memiliki kematangan keperibadian dan mental yang sehat karena para santri tersebut tetap mampu mengatasi segala 
problem hidupnya dan tuntuta-tuntutan diasrama dengan santai dan nyaman.

\section{DAFTAR PUSTAKA}

Ardjanam. (2007). Dipetik Februari 23, 2020, dari http://hakimatulmahmudah.wordpress.com

Bastaman. (2007). Logo Terapi: Psikologi Untuk Menemukan Makna Hidup dan Meraih Hidup Bermakna. Jakarta: Raja Grafindo Persada.

Brizendine. (2005). Dipetik Januari 24, 2020, dari http://journal.uad.ac.id/article

Frankel, J. P., \& Wallen, N. E. (2008). How to Design and Evaluate Research in Education. New York: McGraw-Hill Companies, Inc.

Hartanti. (2008). Apakah Selera Humor Menurunkan Stres? Sebuah Meta-analisis. Anima. Indonesian Psychologycal Journal , 38-55.

Hasan, I. (2012). Pokok-Pokok Materi Statistik 1 (Statistik Deskriptif). Jakarta: Bumi Aksara.

Hurlock, E. B. (2011). Psikologi Perkembangan: Suatu Pendekatan Sepanjang Rentang Kehidupan. Jakarta: Penerbit Erlangga.

Jones, C. L. (2010). The Relationship Between Health Status, Life Satisfaction, and Humor as a Coping Mechanism Among Noninstitutionalized. The Florida State University College of Education.

Looker, T., \& Gregson, O. (2005). Managing Stress: Mengatasi Stres Secara Mandiri. Yogyakarta: BACA.

Lubis, N. L. (2009). Depresi dan Tinjauan Psikologis. Jakarta: Prenada Media Group.

Ripa, E. (2010). Hubungan Antara Sense of Humor Dengan Kreativitas pada Siswa Kelas VII SMP Negeri 13 Malang. Malang: Fakultas Psikologi Universitas Islam Negeri (UIN) Maulana Malik Ibrahim.

Safaria, T., \& Saputra, N. E. (2009). Manajemen Emosi: Sebuah Panduan Cerdas Bagaimana Mengelola Emosi Positif dalam Hidup Anda. Jakarta: Bumi Aksara. 